\title{
Cyclocondensation, antimicrobial activity and semi-empirical AM1-M0 calculations of benzopyrone derivatives
}

\author{
Hafez Mohamed El-Shaaer \\ Department of Chemistry, Faculty of Education, Ain Shams University, Roxy, 11711, Cairo, Egypt \\ *Corresponding author at: Department of Chemistry, Faculty of Education, Ain Shams University, Roxy, 11711, Cairo, Egypt. \\ Tel.: +201.12627069; fax: +202.2581243. E-mail address: elshaaer@hotmail.com (H.M. El-Shaaer).
}

\begin{tabular}{l} 
ARTICLE INFORMATION \\
Received: 13 August 2011 \\
Received in revised form: 06 September 2011 \\
Accepted: 22 September 2011 \\
Online: 31 March 2012 \\
KEYWORDS \\
Synthesis \\
Benzopyrone \\
4-Quinolinone \\
Cyclocondensation \\
AM1-MO calculation \\
Antimicrobial activity \\
\hline
\end{tabular}

\section{Introduction}

Fused coumarins (2H-1-benzopyran-2-ones) comprise a very interesting class of compounds due to their significant antibacterial [1] and pharmacological activities [2]. Also, chromone (4H-1-benzopyran-4-one) derivatives exhibit significant biological activities, such as antifungal [3,4], antimycobacterial [5,6], antialergic [7], antitumour [8-10], and antiviral [11-12]. So, and with the expectative to find biological activity, I decided to investigate the synthesis of some novel systems of coumarin derivatives bearing chromone moiety. Recently, the synthesis [13], photochemical [14] and theoretical [15] properties of chromone derivatives were largely investigated.

The aim of the present paper is to investigate an efficient synthesis of coumarin derivatives containing active methyl and cyano groups and study their cyclocondensation reactions with ethyl cyanoacetate, thiosemicarbazide, ethyl acetate and 6,8dichloro-4-oxo-4H-chromene-3-carboxaldehyde. The antimicrobial activities for the prepared compounds were investigated. Also, semi-empirical AM1 and Ab Initio (STO-3G) molecular orbital calculations for the new compounds were studied and compared with their experimental data.

\section{Experimental}

\subsection{Instrumentation}

The uncorrected melting points were determined in an open capillary tube on a digital Stuart SMP-3 apparatus. ${ }^{1} \mathrm{H} /{ }^{13} \mathrm{C}$ NMR spectra were obtained on a 500/125 MHz Jeol Eca or on a $300 / 75.46 \mathrm{MHz}$ Varian Mercury VX-300 NMR spectrometer in DMSO- $d_{6}$ with tetramethylsilane as an internal standard. Elemental analyses were performed on Vario El Elementar apparatus. IR spectra were recorded on FTIR Nicolet IS10 spectrophotometer $\left(\mathrm{cm}^{-1}\right)$, using $\mathrm{KBr}$ disks. Mass spectra were recorded on a Gas Chromatographic GCMSqp 1000 ex Shimadzu instrument at $70 \mathrm{eV}$. Thermodynamic data were obtained from molecular mechanical calculations on the basis of the semi-empirical AM1 and Ab Initio (STO-3G) methods with the HyperChem 8.03 computer program.

\subsection{Synthesis}

6,8-Dichloro-4-oxo-4H-chromene-3-carboxaldehyde (8) was prepared according to [15]. The other chemicals were purchased from the suppliers as the highest purity grade.

\subsubsection{7-Amino-2,4-dichloro-9-hydroxy-6-oxo-6H-benzo[c] chromene-8-carbonitrile (2)}

A solution of 3,5-dichloro-2-hydroxyacetophenone (1) (4.0 g, $2 \mathrm{mmol})$ in ethyl cyanoacetate $\left(22 \mathrm{~cm}^{3}\right)$, sodium metal $(2 \mathrm{~g}$, 8 mmol) was added by small portion on the solution and the reaction mixture was heated on water-bath for $2 \mathrm{~h}$ and then heated under reflux for $1 \mathrm{~h}$. The product was treated with water and acidified with acetic acid. The solid obtained was filtered, and crystallized from acetic acid to give $\mathbf{2}$ as yellow crystals (Scheme 1).

7-Amino-2,4-dichloro-9-hydroxy-6-oxo-6H-benzo[c]chrome ne-8-carbonitrile (2): Yield: 29\%. M.p.: 270-272 ${ }^{\circ} \mathrm{C}$. FT-IR (KBr, $\mathrm{cm}^{-1}$ ): 3350, 3260, 3197, 3064, 2981, 2209, 1736, 1682, 1616 ${ }^{1} \mathrm{H}$ NMR (300 MHz, DMSO- $\left.d_{6}\right): 2.50\left(\mathrm{~m}, 3 \mathrm{H}, \mathrm{CH}, \mathrm{CH}_{2}\right), 4.19(\mathrm{~m}$, $2 \mathrm{H}, \mathrm{NH}_{2}$, exchangeable with $\left.\mathrm{D}_{2} \mathrm{O}\right), 8.02-8.09(\mathrm{~m}, 2 \mathrm{H}, \mathrm{H}-1$ and $\mathrm{H}-$ 3), $8.88\left(\mathrm{~s}, 1 \mathrm{H}\right.$, exchangeable with $\left.\mathrm{D}_{2} \mathrm{O}\right), 9.19(\mathrm{~s}, 1 \mathrm{H}$, exchangeable with $\left.\mathrm{D}_{2} 0\right) .{ }^{13} \mathrm{C}$ NMR $\left(75.46 \mathrm{MHz}\right.$, DMSO- $\left.d_{6}\right): 60.0$, 72.0, 109.2, 117.5, 120.7, 120.9, 121.4, 122.3, 125.1, 129.1, 132.5, 146.6, 150.4, 155.8, 163.2, 166.1. MS (EI, m/z (\%)): $322.4(\mathrm{M}+1,15.9), 322.8(\mathrm{M}+2,18.2)$.

European Journal of Chemistry 


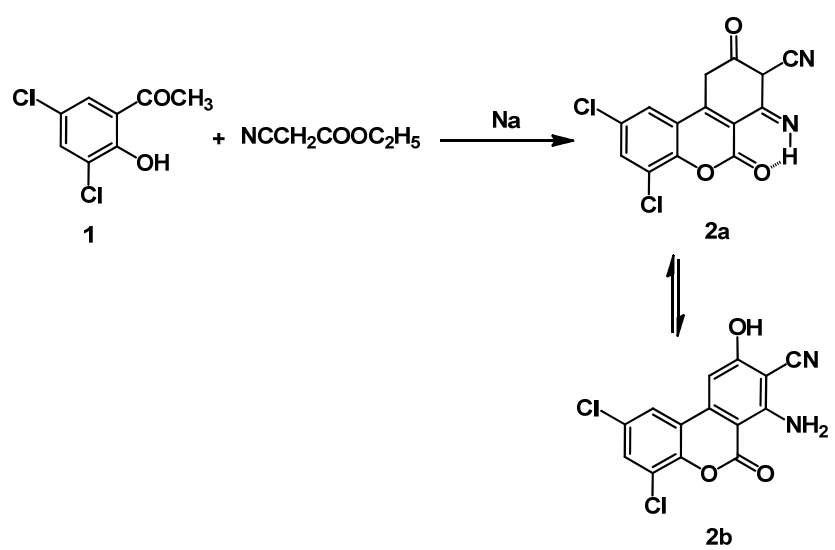

Scheme 1

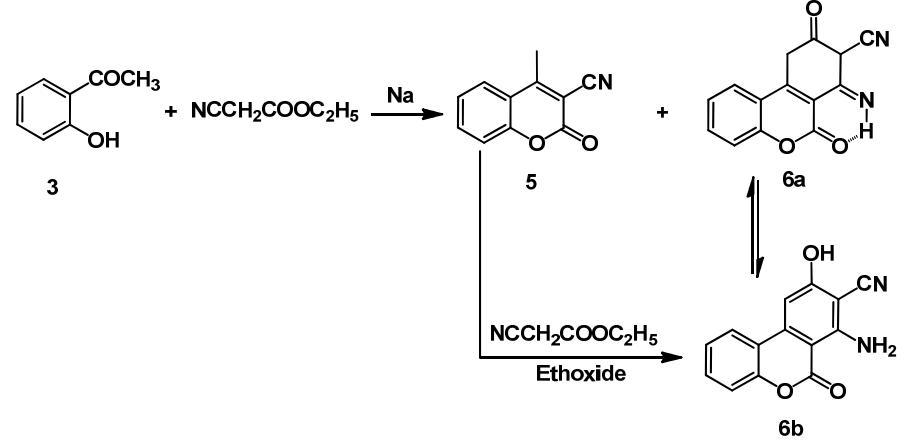

Scheme 2

Anal. calcd. for $\mathrm{C}_{14} \mathrm{H}_{6} \mathrm{Cl}_{2} \mathrm{~N}_{2} \mathrm{O}_{3}$ : C, 52.36; $\mathrm{H}, 1.88 ; \mathrm{N}, 8.72$. Found: C, 52.54; H, 2.00, N, 8.72\%.

\subsubsection{4-Methyl-2-oxo-2H-chromene-3-carbonitrile (5) and 7- amino-9-hydroxy-6-oxo-6H-benzo[c]chromene-8- carbonitrile (6)}

Method A: Sodium metal (10 g, $43 \mathrm{mmol})$ was added in small portion to a solution of 2-hydroxyacetophenone (3) (20.0 $\mathrm{g}, 15 \mathrm{mmol})$ in ethyl cyanoacetate $\left(110 \mathrm{~cm}^{3}\right)$. The reaction mixture was heated on water-bath for $3 \mathrm{~h}$, and then cooled to room temperature, treated with ethanol $\left(30 \mathrm{~cm}^{3}\right)$ and refluxed for $1 \mathrm{~h}$. The solid obtained was filtered, and crystallized from cyclohexane to give $\mathbf{5}$ as yellow crystals, Yield: 20\%. M.p.: 192$194{ }^{\circ} \mathrm{C}$ (Scheme 2 and 3). The ethanolic filtrate was concentrated to its half amount, acidified with $96 \%$ acetic acid and diluted with water to give $\mathbf{6}$ as pall-yellow crystals, Yield: $30 \%$. M.p.: $237-238^{\circ} \mathrm{C}$ (acetic acid).

4-Methyl-2-oxo-2H-chromene-3-carbonitrile (5): FT-IR (KBr, $\left.\mathrm{cm}^{-1}\right): 3060,2920,2228,1723,1600 .{ }^{1} \mathrm{H}$ NMR $(500 \mathrm{MHz}$, DMSO$\left.d_{6}\right): 2.69\left(\mathrm{~s}, 3 \mathrm{H}, \mathrm{CH}_{3}\right), 7.44-7.47(\mathrm{~m}, 2 \mathrm{H}, H-6$ and $H-8), 7.76(\mathrm{t}, J=$ $7.65 \mathrm{~Hz}, 1 \mathrm{H}, H-7), 7.95$ (d, $J=8.45 \mathrm{~Hz}, 1 \mathrm{H}, H-5) .{ }^{13} \mathrm{C}$ NMR (125 MHz, DMSO- $d_{6}$ ): 18.7 (-), 101.8 (quat), 114.8 (quat), 117.5 (+), 118.6 (quat), $125.8(+), 127.6(+), 135.8(+), 153.2$ (quat), 157.3 (quat), 164.2 (quat). MS (EI, m/z (\%)): 184 (M-1, 13.7), 185 (M, 100.0), $186(\mathrm{M}+1,12.1)$. Anal. calcd. for $\mathrm{C}_{11} \mathrm{H}_{7} \mathrm{NO}_{2}: \mathrm{C}, 71.35 ; \mathrm{H}$, 3.81; N, 7.56. Found: C, 71.70; H, 3.50; N, 7.76\%.

7-amino-9-hydroxy-6-oxo-6H-benzo[c]chromene-8carbonitrile (6): FT-IR (KBr, cm$\left.{ }^{-1}\right)$ : 3370, 3282, 3220, 3079, 2987, 2211, 1705, 1638, 1609. ${ }^{1} \mathrm{H}$ NMR (300 MHz, DMSO-d6): $2.47\left(\mathrm{~m}, 3 \mathrm{H}, \mathrm{CH}, \mathrm{CH}_{2}\right), 4.22\left(\mathrm{~m}, 2 \mathrm{H}, \mathrm{NH}_{2}\right.$, exchangeable with $\left.\mathrm{D}_{2} \mathrm{O}\right), 7.43-7.49(\mathrm{~m}, 2 \mathrm{H}, H-2$ and $H-3), 7.72(\mathrm{dd}, J=7.2,1.2 \mathrm{~Hz}$, $1 \mathrm{H}, H-4), 7.93(\mathrm{dd}, J=9.0,1.2 \mathrm{~Hz}, 1 \mathrm{H}, H-1), 9.00,(\mathrm{~s}, 1 \mathrm{H}$, exchangeable with $\left.\mathrm{D}_{2} \mathrm{O}\right), 9.26\left(\mathrm{~s}, 1 \mathrm{H}\right.$, exchangeable with $\left.\mathrm{D}_{2} \mathrm{O}\right)$. ${ }^{13} \mathrm{C}$ NMR $\left(75.46 \mathrm{MHz}\right.$, DMSO- $d_{6}$ ): 59.9, 72.1, 116.5, 117.7, 118.5, 121.0, 124.9, 126.2, 133.2, 151.0, 152.2, 157.1, 164.3, 166.4. MS (EI, m/z (\%)): 252.5 (M, 5.1). Anal. calcd. for $\mathrm{C}_{14} \mathrm{H}_{8} \mathrm{~N}_{2} \mathrm{O}_{3}$ : 66.67; H, 3.20; N, 11.11. Found: C, 66.52; H, 3.00; N, 11.50\%.

Method B: A solution of compound $5(0.5 \mathrm{~g}, 0.27 \mathrm{mmol})$ in ethoxide ( $0.15 \mathrm{~g}$ sodium, $10 \mathrm{~cm}^{3}$ absolute ethanol), and then ethyl cyanoacetate $\left(1.0 \mathrm{~cm}^{3}\right)$ was added and the mixture was refluxed on water-bath for $2 \mathrm{~h}$, cooled to room temperature and acidified with $96 \%$ acetic acid. The solid obtained was filtered, and crystallized from acetic acid to give $\mathbf{6}$ as pall-yellow crystals (Scheme 2). M.p.: 237-238 ${ }^{\circ}$ C. Yield: 59\%.

\subsubsection{1-(3-Cyano-4-methyl-2-oxoquinolin-1(2H)-yl)thiourea (7)}

A mixture of compound $5(0.25 \mathrm{~g}, 0.13 \mathrm{mmol})$ and thiosemicarbazide $(0.15 \mathrm{~g}, 0.16 \mathrm{mmol})$ in pyridine $\left(2 \mathrm{~cm}^{3}\right)$ was refluxed for $5 \mathrm{~h}$. The solid obtained was filtered, and crystallized from ethanol to give $\mathbf{7}$ as orange crystals (Scheme 4 and 5).

1-(3-Cyano-4-methyl-2-oxoquinolin-1(2H)-yl)thiourea (7): Yield: $73 \%$. M.p.: $186-187^{\circ} \mathrm{C}$. FT-IR (KBr, cm$\left.{ }^{-1}\right)$ : 3368, 3263 , 3177, 3061, 2923, 2228, 1724, 1601. 1 H NMR (300 MHz, DMSO$\left.d_{6}\right): 2.73\left(\mathrm{~s}, 3 \mathrm{H}, \mathrm{CH}_{3}\right), 4.47\left(\mathrm{~s}, 2 \mathrm{H}, \mathrm{NH}_{2}\right.$, exchangeable with $\mathrm{D}_{2} \mathrm{O}$ ), 7.45-7.50 (m, $2 \mathrm{H}, H-6$ and $H-8$ ), 7.77 (dd, $J=7.8,1.8 \mathrm{~Hz}, 1 \mathrm{H}, H-$ 5), 7.93 (dd, $J=7.8,6.3 \mathrm{~Hz}, 1 \mathrm{H}, H-7), 8.55(\mathrm{~s}, 1 \mathrm{H}, \mathrm{NH}$ exchangeable with $\left.\mathrm{D}_{2} \mathrm{O}\right) .{ }^{13} \mathrm{C}$ NMR $\left(75.46 \mathrm{MHz}\right.$, DMSO- $d_{6}$ ): 18.1, $101.2,114.1,116.9,118.0,120.7,125.2,127.0,135.2,152.6$ 156.6, 163.6. MS (EI, m/z (\%)): 256 (M-2, 16.7), 257 (M-1, 16.7), 258 (M, 13.3). Anal. calcd. for $\mathrm{C}_{12} \mathrm{H}_{10} \mathrm{~N}_{4} \mathrm{OS}$ : C, 55.80; $\mathrm{H}$ 3.90; N, 21.69; S, 12.41. Found: C, 55.59; H, 4.00; N, 21.20; S, $12.15 \%$. 


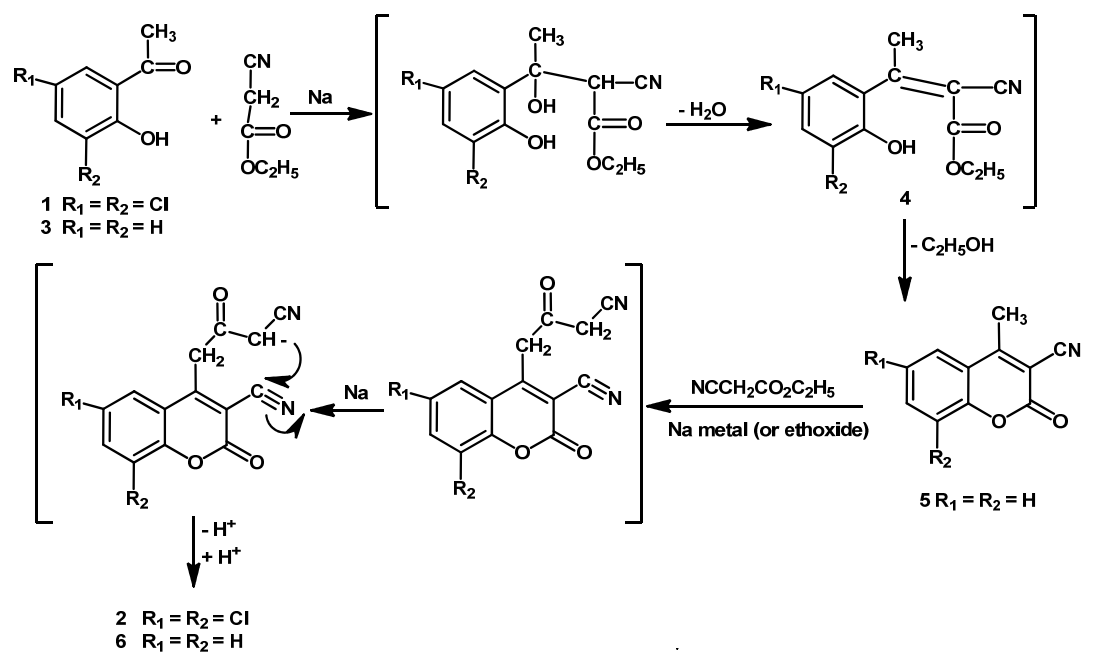

Scheme 3

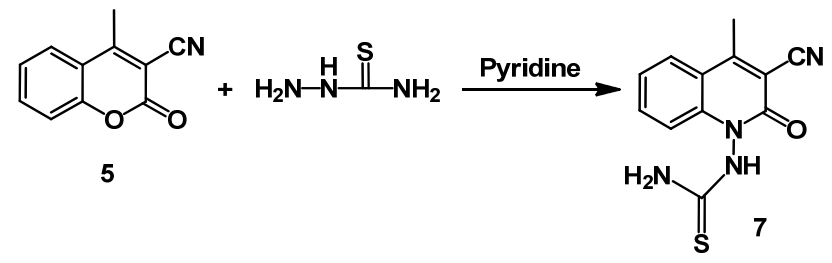

Scheme 4

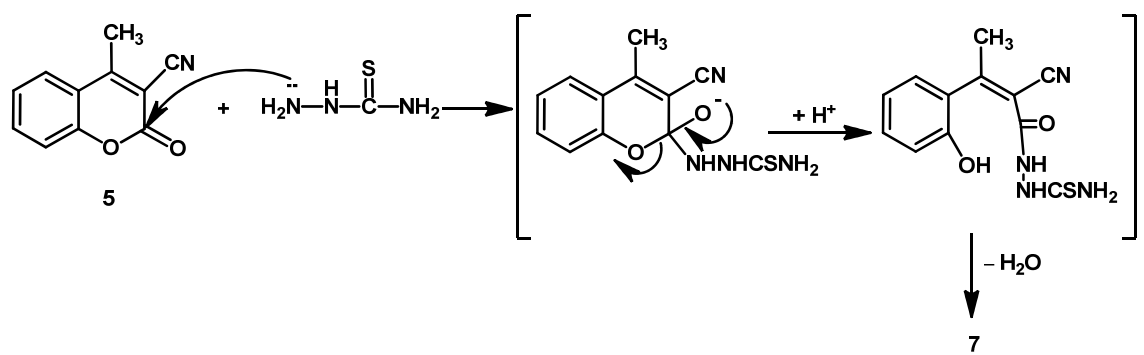

Scheme 5

\subsubsection{4-(2-(6,8-Dichloro-4-oxo-4H-chromen-3-yl)-2- hydroxyethyl)-2-oxo-2H-chromene-3-carbonitrile (9)}

Method A: A mixture of compound $5(0.5 \mathrm{~g}, 0.27 \mathrm{mmol})$ and 6,8-dichloro-4-oxo-4H-chromene-3-carboxaldehyde (8) $(0.66 \mathrm{~g}$, $0.27 \mathrm{mmol})$ in dimethylformamide $\left(10 \mathrm{~cm}^{3}\right)$ was stirred at room temperature $\left(25^{\circ} \mathrm{C}\right)$ for $4 \mathrm{~h}$, leave overnight, filtered off and crystallized from acetic acid to give $\mathbf{9}$ as a white crystals (Scheme 6).

4-(2-(6,8-Dichloro-4-oxo-4H-chromen-3-yl)-2-hydroxyethyl)2-oxo-2H-chromene-3-carbonitrile (9): Yield: 60\%. M.p.: 293$294{ }^{\circ} \mathrm{C}$. FT-IR (KBr, cm-1): 3743 (br), 3060, 2226, 1727, 1652. ${ }^{1} \mathrm{H}$ NMR (500 MHz, DMSO-d $d_{6}$ ): 2.07 (d, $J=6.9 \mathrm{~Hz}, 2 \mathrm{H}, \mathrm{CH}_{2}$ ), 2.85 (br. s, $1 \mathrm{H}, \mathrm{CH}$ ), 7.39-7.52 (m, 2H, Ar- $H$ ), 7.80 (s, 1H, H-7), 7.94 (d, $J=8.4 \mathrm{~Hz}, 1 \mathrm{H}, \mathrm{Ar}-H$ ), 8.04 (s, $1 \mathrm{H}, H-5$ ), 8.24 (dd, $J=9.95,6.1$ $\mathrm{Hz}, 1 \mathrm{H}, \mathrm{Ar}-H$ ) 9.08 (s, $1 \mathrm{H}, H-2), 10.05$ (s, 1H, OH). MS (EI, m/z (\%)): $410\left(\mathrm{M}-\mathrm{H}_{2} \mathrm{O}, 43.3\right)$. Anal. calcd. for $\mathrm{C}_{21} \mathrm{H}_{11} \mathrm{Cl}_{2} \mathrm{NO}_{5}$ : C, 58.90; H, 2.59; N, 3.27. Found: C, 58.75; H, 2.23; N, 3.56\%.
Method B: A mixture of compound $5(0.5 \mathrm{~g}, 0.27 \mathrm{mmol})$ and 6,8-dichloro-4-oxo-4H-chromene-3-carboxaldehyde (8) (0.66 g, $0.27 \mathrm{mmol})$ in dimethylformamide $\left(5 \mathrm{~cm}^{3}\right)$ was refluxed for 5 min. The solid obtained was filtered and purified in the same manner as in method A, Yield: 69\%.

\subsubsection{7-((6,8-Dichloro-4-oxo-4H-chromen-3- yl)methyleneamino)-9-hydroxy-6H-benzo[c]chromen-6-one (12)}

A solution of compound 5 ( $0.5 \mathrm{~g}, 0.27 \mathrm{mmol})$ in ethoxide ( $0.15 \mathrm{~g}$ sodium, $10 \mathrm{~cm}^{3}$ absolute ethanol), and then ethyl acetate $\left(1.0 \mathrm{~cm}^{3}\right)$ was added and the mixture was refluxed on water-bath for $2 \mathrm{~h}$, cooled to room temperature and filtered off. The solid obtained $(0.27 \mathrm{~g})$ was mixed with acetic acid $(2.5$ $\left.\mathrm{cm}^{3}\right)$, sodium acetate $(0.3 \mathrm{~g})$ and 6,8-dichloro-4-oxo-4Hchromene-3-carboxaldehyde $(0.26 \mathrm{~g}, 0.1 \mathrm{mmol})$ and refluxed for $1 \mathrm{~h}$, filtered off and crystallized from ethanol to give $\mathbf{1 2}$ as a pale orange crystals (Scheme 7). 


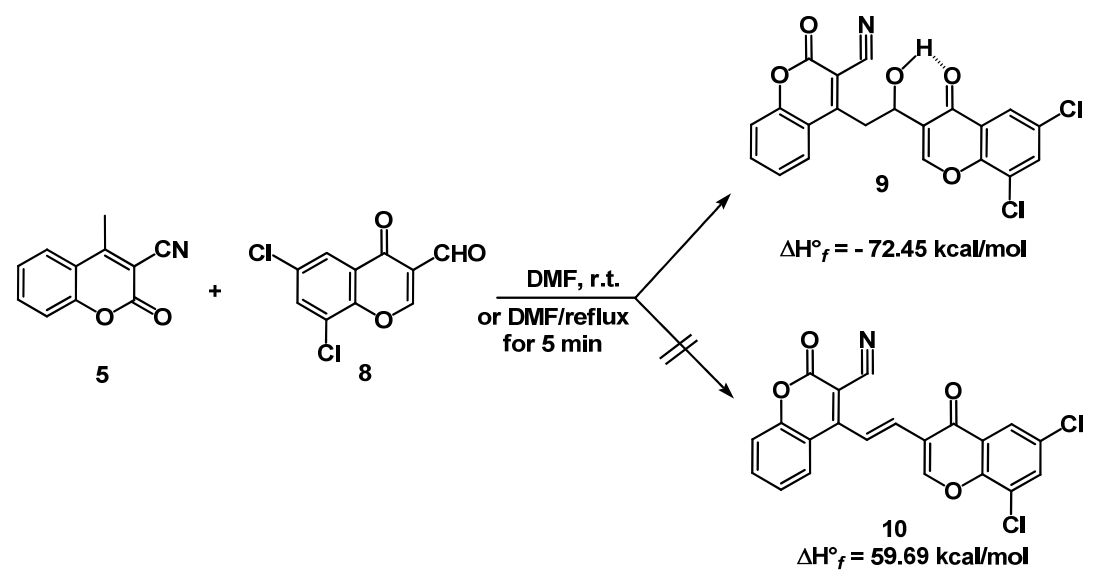

Scheme 6

7-((6,8-Dichloro-4-oxo-4H-chromen-3-yl)methyleneamino)9-hydroxy-6H-benzo[c]chromen-6-one (12): Yield: 65\%. M.p.: 183-184 ${ }^{\circ} \mathrm{C}$. FT-IR (KBr, cm${ }^{-1}$ ): 3431 (br), 3075, 1716, 1653, 1602. ${ }^{1} \mathrm{H}$ NMR (500 MHz, DMSO- $\left.d_{6}\right): 6.69(\mathrm{~s}, 1 \mathrm{H},-\mathrm{CH}=N), 7.25$ (s, $1 \mathrm{H}, \mathrm{Ar}-H), 7.37-7.43(\mathrm{~m}, 2 \mathrm{H}, \mathrm{Ar}-H), 7.63-7.72(\mathrm{~m}, 3 \mathrm{H}, \mathrm{Ar}-H)$, 7.96 (s, $1 \mathrm{H}, H-5), 8.02$ (s, $1 \mathrm{H}, H-2), 8.16-8.22$ (m, 1H, Ar- $H$ ), 8.92 (s, $1 \mathrm{H}, \quad \mathrm{OH}$, exchangeable with $\left.\mathrm{D}_{2} \mathrm{O}\right)$. Anal. calcd. for $\mathrm{C}_{23} \mathrm{H}_{11} \mathrm{Cl}_{2} \mathrm{NO}_{5}$ : C, 61.08; $\mathrm{H}, 2.45 ; \mathrm{N}, 3.10$. Found: $\mathrm{C}, 61.42 ; \mathrm{H}, 2.15$; $\mathrm{N}, 2.75 \%$.

\subsection{Antimicrobial activity}

The newly synthesized compounds were screened against Gram-positive bacteria: Staphylococcus aureus (ATCC 25923) and Bacillus subtilis (ATCC 6635), Gram-negative bacteria: Salmonella typhimurium (ATCC 14028) and Escherichia coli (ATCC 25922), Yeast: Candida albicans (ATCC 10231) and Fungus: Aspergillus fumigatus. The standardized disc-agar diffusion method [16] was followed to determine the activity of the synthesized compounds against the tested microorganisms.

The tested compounds were dissolved in dimethyl formamide (DMF) solvent and prepared in two concentrations 2 and $1 \mathrm{mg} / \mathrm{mL}$. The antibiotic chloramphencol was used as standard reference in the case of Gram-negative bacteria, Cephalothin was used as standard reference in the case of Gram-positive bacteria and Cycloheximide was used as standard reference in the case of yeasts and fungi.

\section{Results and discussion}

\subsection{Chemistry}

The Claisen condensation of 2-hydroxyacetophenone derivatives with ethyl acetate in the presence of sodium metal gave $\beta$-dicarbonyl compound derivatives which were cyclized under the effect of conc. sulfuric acid to give 2-methylchromone derivatives [15].

The novel and unexpected Claisen condensation of 3,5dichloro-2-hydroxyacetophenone (1) with excess of ethyl cyanoacetate in the presence of sodium metal gave 7-amino2,4-dichloro-9-hydroxy-6-oxo-6H-benzo[c]chromene-8-carbonitrile (2) (Scheme 1), but when unsubstituted 2hydroxyacetophenone (3) reacted under the same condition gave a mixture of 4-methyl-2-oxo- $2 \mathrm{H}$-chromene-3-carbonitrile (5) $(20 \%)$ and 7-amino-9-hydroxy-6-oxo-6H-benzo $[c]$ chromene-8-carbonitrile (6) (30\%). When compound 5 was reacted with ethyl cyanoacetate in the presence of sodium ethoxide gave compound (6) (59\%) (Scheme 2).
The formation of compounds $\mathbf{2}$ and $\mathbf{6}$ proceeded via $\alpha, \beta$ unsaturated ester derivatives (4), which can be cyclized under the effect of heat to give compound 5, further Claisen condensation on active methyl group of compound $\mathbf{5}$ followed by nucleophilic cyclization gave compounds $(\mathbf{2}, \mathbf{6})$ (Scheme 3 ).

The Claisen condensation of 3,5-dichloro-2-hydroxyacetophenone (1) with ethyl cyanoacetate gave only cyclocondensation product $\mathbf{2 a} \rightleftharpoons \mathbf{2 b}$, while unsubstituted 2hydroxyacetophenone (3) gave a mixture of condensation product $\mathbf{5}$ and cyclocondensation product $\mathbf{6 a} \rightleftharpoons \mathbf{6 b}$ due to the thermodynamic stabilities of $\mathbf{2 a} \rightleftharpoons \mathbf{2 b}$ than $\mathbf{6 a} \rightleftharpoons \mathbf{6 b}$ (Table 1). Also, theoretical thermodynamic data obtained from semiempirical AM1-MO calculations shows that structure $\mathbf{2 b}$ is more stabilized than $\mathbf{2 a}$ and $\mathbf{6 b}$ than $\mathbf{6 a}$ (Table 1 ).

Table 1. Calculated heat of formation of coumarin derivatives by semiempirical AM1-MO method.

\begin{tabular}{ll}
\hline Compound & Heat of formation $(\mathrm{kcal} / \mathbf{m o l})$ \\
\hline $2 \mathrm{a}$ & -13.65 \\
$2 \mathrm{~b}$ & -43.63 \\
5 & -2.51 \\
$6 \mathrm{a}$ & -5.21 \\
$6 \mathrm{~b}$ & -34.77 \\
9 & -72.45 \\
10 & 59.69 \\
\hline
\end{tabular}

The presence of cyano group in a 3-position of coumarin moiety facilitate the nucleophilic ring addition on $\mathrm{C}=0$ group followed by ring fission and recyclization, so the reaction of thiosemicarbazide with compound 5 in pyridine gave 1-(3cyano-4-methyl-2-oxoquinolin-1(2H)-yl)thiourea (7) (Scheme 4 ) and the mechanism of formation of compound 7 (Scheme 5).

The reaction of compound 5 with 6,8-dichloro-4-oxo- $4 \mathrm{H}$ chromene-3-carboxaldehyde (8) in dimethylformamide at room temperature $\left(25^{\circ} \mathrm{C}\right)$ and/or reflux for $5 \mathrm{~min}$ gave addition product 9 rather than the condensation product $\mathbf{1 0}$. The preferable formation of $\mathbf{9}$ rather than $\mathbf{1 0}$ seems to be due to the thermodynamic stabilities according to semi-empirical AM1 calculation data, where the $\Delta \mathrm{H}^{\circ}{ }_{f}=-72.45 \mathrm{kcal} / \mathrm{mol}$ for 9 which is much more stabilized than $\Delta \mathrm{H}^{\circ}{ }_{f}=59.69 \mathrm{kcal} / \mathrm{mol}$ of $\mathbf{1 0}$ (Table 1) and also for the presence of strong hydrogen bond between the $\mathrm{C}=\mathrm{O}$ and the $\mathrm{OH}$ groups of chromone moiety of compound 9 (Scheme 6).

The Claisen condensation of compound $\mathbf{5}$ with ethyl acetate in the presence of sodium ethoxide gave the sodium salt of 7amino-9-hydroxy-6H-benzo[c]chromen-6-one (11) as intermediate product which upon treatment with 8 in acetic acid and sodium acetate gave 7-((6,8-dichloro-4-oxo- $4 H$ chromen-3-yl)methyleneamino)-9-hydroxy-6H-benzo[c] chromen-6-one (12) (Scheme 7). 


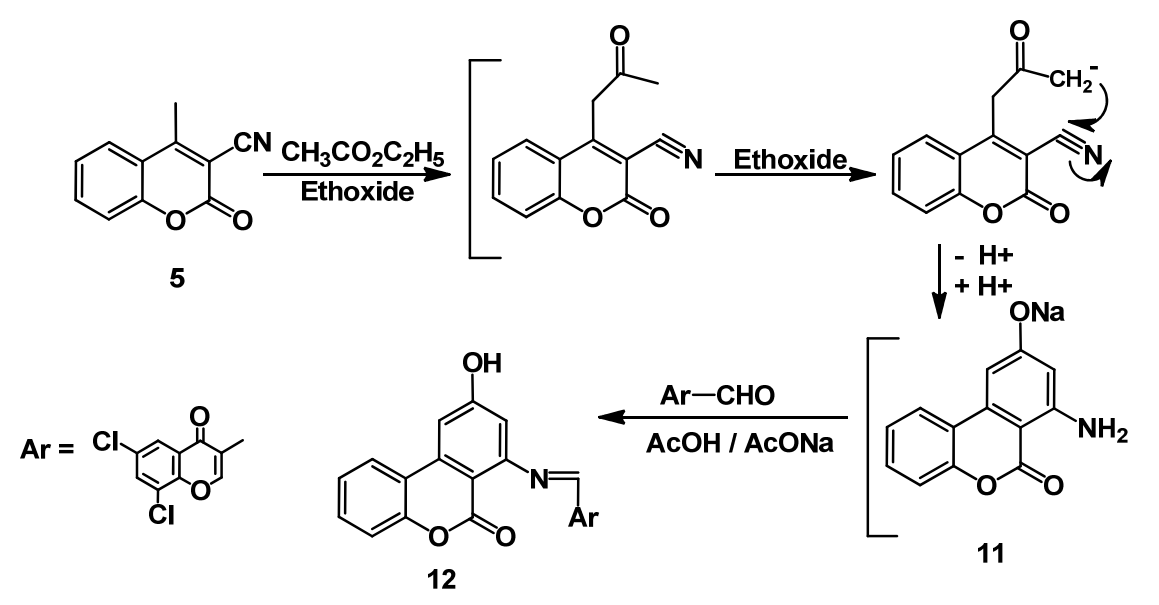

Scheme 7

\subsection{Molecular orbital calculations}

The experimental IR frequencies of $\mathrm{C}=0$ groups of coumarin derivatives were compared with theoretical bond lengths of $\mathrm{C}=\mathrm{O}$ groups which were obtained from molecular mechanical calculations on the basis of the semi-empirical AM1 and Ab Initio (STO-3G) methods of HyperChem 8.03 computer program after geometrical optimization of the structures for compounds (2-12) (Table 2).

Table 2. Calculated bond lengths of $\mathrm{C}=\mathrm{O}$ of coumarin derivatives by semiempirical AM1 and Ab Initio (STO-3G) methods and their experimental IR $v_{\mathrm{C}=0}$ values for compounds (2a-12).

\begin{tabular}{|c|c|c|c|}
\hline \multirow[b]{2}{*}{ Compound } & \multicolumn{2}{|c|}{ Bond lengths of $\mathrm{C}=0, \AA$} & \multirow{2}{*}{$\begin{array}{l}\text { Experimenta } \\
v_{C}=0\left(\mathrm{~cm}^{-1}\right)\end{array}$} \\
\hline & $\begin{array}{l}\text { Semi-empirical } \\
\text { (AM1) }\end{array}$ & $\begin{array}{l}\text { Ab Initio } \\
\text { (ST0-3G) }\end{array}$ & \\
\hline$\overline{2 a}$ & $1.22484^{a}$ & 1.21413 & 1736 \\
\hline $2 a$ & $1.2303^{\mathrm{b}}$ & 1.21421 & 1682 \\
\hline 5 & $1.228^{\mathrm{a}}$ & 1.217 & 1723 \\
\hline $6 a$ & $1.22623^{\mathrm{a}}$ & 1.21621 & 1705 \\
\hline $6 a$ & $1.2309 \mathrm{~b}$ & 1.21456 & 1680 \\
\hline 7 & $1.2353^{c}$ & 1.2208 & 1724 \\
\hline 9 & $1.22853^{\mathrm{a}}$ & 1.21732 & 1727 \\
\hline 9 & $1.23831^{\mathrm{b}}$ & 1.44367 & 1652 \\
\hline 12 & $1.22777^{a}$ & 1.21652 & 1716 \\
\hline 12 & $1.23908^{\mathrm{b}}$ & 1.45056 & 1653 \\
\hline$r^{\mathrm{d}}$ & 0.914 & 0.987 & - \\
\hline \multicolumn{4}{|c|}{${ }^{\mathrm{a}} \mathrm{C}=\mathrm{O}_{\text {coumarin }}$} \\
\hline \multicolumn{4}{|c|}{ b $\mathrm{C}=\mathrm{O}_{\text {chromone or cyclic ketone }}$} \\
\hline \multicolumn{4}{|c|}{ c $\mathrm{C}=\mathrm{O}_{\text {quinolinone }}$} \\
\hline
\end{tabular}

The calculated bond lengths of $\mathrm{C}=0$ groups $(\AA)$ on the basis of semi-empirical AM1 method are linearly related to the measured IR UC=0 groups $\left(\mathrm{cm}^{-1}\right)$ for compounds (2-12) and from the linear relation bond length $(\mathrm{C}=0)=1.47-0.001 \mathrm{vC}=0$, $r=0.9140$ except (7), where $r$ is regression coefficient. The negative slope reveals indirect proportionality of the calculated bond lengths with measured $v_{c}=0$ values, which agreement with Hooke's law and these support the proposed structures for the prepared compounds. On the other hand, when Ab Initio (STO3G) method was used, the linear relation bond length $(\mathrm{C}=0)=$ $1.11+6.25 \times 10^{-5}$ vc=0, $r=0.9870$ except $(\mathbf{2 a}, 7,9 \mathbf{b}$ and $\mathbf{1 2 b})$ which is less efficient method than the last method.

Also, the calculated net carbon charges by semi-empirical AM1 and Ab Initio (STO-3G) methods after geometrical optimization were compared with experimental ${ }^{13} \mathrm{C}$ NMR $\delta$ values for compound $\mathbf{5}$ (Table 3).

The calculated net carbon charges on the basis of semiempirical AM1 method are linearly related to the experimental ${ }^{13} \mathrm{C}$ NMR ( $\delta$ in ppm) for compound 5 and from the linear relation charges on carbon atoms $=-0.74+0.005{ }^{13} \mathrm{C}$ NMR, $r=0.9200$, except (C-2 and C-10), where $r$ is regression coefficient. The positive slope reveals direct proportionality of the calculated net carbon charges with measured ${ }^{13} \mathrm{C}$ NMR $\delta$ values, which support the proposed structure for compound $\mathbf{5}$. Also, when Ab Initio (STO-3G) method was used, the linear relation charges on carbon atoms $=-0.25+0.002{ }^{13} \mathrm{C} \mathrm{NMR}$, $r=0.8340$, except (C-2 and C-9), which less agreement with experimental data than semi-empirical AM1 method. The dependence of ${ }^{13} \mathrm{C}$ NMR shifts on the net carbon charges for compound $\mathbf{5}$ is more pronounced than that found of IR (Uc=0) and their bond lengths for compounds (2-12), as indicated from slope values of semi-empirical AM1 method.

Table 3. Calculated net carbon charges by semi-empirical AM1 and Ab Initio (STO-3G) methods and their experimental ${ }^{13} \mathrm{C}$ NMR values for compound $\mathbf{5}$.

\begin{tabular}{|c|c|c|c|}
\hline \multirow{2}{*}{$\begin{array}{l}\text { Carbon } \\
\text { number }\end{array}$} & \multicolumn{2}{|c|}{ Calculated net carbon charges } & \multirow{2}{*}{$\begin{array}{l}\text { Experimental } \\
{ }^{13} \mathrm{C} \text { NMR } \delta(\mathrm{ppm})\end{array}$} \\
\hline & $\begin{array}{l}\text { Semi-empirical } \\
\text { (AM1) }\end{array}$ & $\begin{array}{l}\text { Ab Initio } \\
\text { (ST0-3G) }\end{array}$ & \\
\hline$\overline{\mathrm{C}-2}$ & 0.350 & 0.319 & 164.24 \\
\hline $\mathrm{C}-3$ & -0.125 & -0.042 & 118.66 \\
\hline$C-4$ & 0.098 & 0.066 & 153.25 \\
\hline C-5 & -0.067 & -0.048 & 135.86 \\
\hline C-6 & -0.159 & -0.070 & 117.54 \\
\hline C-7 & -0.073 & -0.043 & 127.69 \\
\hline C-8 & -0.150 & -0.075 & 125.89 \\
\hline C-9a & -0.153 & -0.036 & 101.85 \\
\hline $\mathrm{C}-10 \mathrm{a}$ & 0.118 & 0.142 & 157.32 \\
\hline C-9 & -0.086 & 0.073 & 114.80 \\
\hline $\mathrm{C}-10$ & -0.210 & -0.189 & 18.79 \\
\hline$r^{*}$ & 0.920 & 0.834 & - \\
\hline
\end{tabular}

\subsection{Antimicrobial activity}

The newly synthesized compounds were screened against Gram-positive bacteria: Staphylococcus aureus (ATCC 25923) and Bacillus subtilis (ATCC 6635), Gram-negative bacteria: Salmonella typhimurium (ATCC 14028) and Escherichia coli (ATCC 25922), Yeast: Candida albicans (ATCC 10231) and Fungus: Aspergillus fumigatus. The standardized disc-agar diffusion method [11] was followed to determine the activity of the synthesized compounds against the tested microorganisms.

Compound 12 showed high activities against Aspergillus fumigates at concentration of $2 \mathrm{mg}$ and $1 \mathrm{mg}$, while it showed intermediate activities against Bacillus subtilis, Escherichia coli and Candida albicans. Compound 9 showed intermediate activities against Bacillus subtilis, Escherichia coli and Candida albicans (Table 4). 
Table 4. Antimicrobial activities data of compounds 2-12.

\begin{tabular}{|c|c|c|c|c|c|c|c|c|c|c|c|c|}
\hline \multirow{4}{*}{$\begin{array}{l}\text { Sample } \\
\text { Conc.g } \\
\end{array}$} & \multicolumn{12}{|c|}{ Mean of zone diametera, $\mathrm{mm}$} \\
\hline & \multicolumn{4}{|c|}{ Gram-positive bacteria } & \multicolumn{4}{|c|}{ Gram-negative bacteria } & \multicolumn{4}{|c|}{ Yeasts $^{\mathrm{b}}$} \\
\hline & \multicolumn{2}{|c|}{$\begin{array}{c}\text { Staphylococcus } \\
\text { aureus } \\
\text { (ATCC 25923) }\end{array}$} & \multicolumn{2}{|c|}{$\begin{array}{c}\text { Bacillus } \\
\text { subtilis } \\
\text { (ATCC 6635) }\end{array}$} & \multicolumn{2}{|c|}{$\begin{array}{c}\text { Salmonella } \\
\text { typhimurium } \\
\text { (ATCC 14028) }\end{array}$} & \multicolumn{2}{|c|}{$\begin{array}{c}\text { Escherichia } \\
\text { coli } \\
\text { (ATCC 25922) }\end{array}$} & \multicolumn{2}{|c|}{$\begin{array}{c}\text { Candida } \\
\text { Albicans } \\
\text { (ATCC 10231) }\end{array}$} & \multicolumn{2}{|c|}{$\begin{array}{l}\text { Aspergillus } \\
\text { fumigatus }\end{array}$} \\
\hline & 2 & 1 & 2 & 1 & 2 & 1 & 2 & 1 & 2 & 1 & 2 & 1 \\
\hline 2 & $4 \mathrm{~L}^{\mathrm{d}}$ & $2 \mathrm{~L}$ & $3 \mathrm{~L}$ & $-\mathrm{c}$ & $2 \mathrm{~L}$ & - & $4 \mathrm{~L}$ & $2 \mathrm{~L}$ & $2 \mathrm{~L}$ & - & - & - \\
\hline 5 & $3 \mathrm{~L}$ & $2 \mathrm{~L}$ & $3 \mathrm{~L}$ & - & $2 \mathrm{~L}$ & - & $2 \mathrm{~L}$ & - & $7 \mathrm{~L}$ & $4 \mathrm{~L}$ & - & - \\
\hline 7 & - & - & $6 \mathrm{~L}$ & $4 \mathrm{~L}$ & - & - & $3 \mathrm{~L}$ & - & $9 \mathrm{~L}$ & $5 \mathrm{~L}$ & $2 \mathrm{~L}$ & - \\
\hline 6 & - & - & $6 \mathrm{~L}$ & $4 \mathrm{~L}$ & - & - & $3 \mathrm{~L}$ & - & $9 \mathrm{~L}$ & $5 \mathrm{~L}$ & $2 \mathrm{~L}$ & - \\
\hline 9 & $8 \mathrm{~L}$ & $5 \mathrm{~L}$ & $15 \mathrm{I}^{\mathrm{e}}$ & $11 \mathrm{I}$ & - & - & $18 \mathrm{I}$ & 12 I & $18 \mathrm{I}$ & $13 \mathrm{I}$ & $8 \mathrm{~L}$ & $5 \mathrm{~L}$ \\
\hline 12 & $6 \mathrm{~L}$ & $3 \mathrm{~L}$ & $13 \mathrm{I}$ & $9 \mathrm{~L}$ & $4 \mathrm{~L}$ & - & $17 \mathrm{I}$ & $12 \mathrm{I}$ & $20 \mathrm{I}$ & $17 \mathrm{I}$ & $28 \mathrm{H}^{\mathrm{f}}$ & $20 \mathrm{H}$ \\
\hline Control ${ }^{\mathrm{h}}$ & 42 & 28 & 38 & 30 & 36 & 25 & 38 & 30 & 40 & 28 & 40 & 31 \\
\hline
\end{tabular}

a Calculate from 3 values.

b Identified on the basis of routine cultural, morphological and microscopical characteristics.

c -: No effect.

d L: Low activity = Mean of zone diameter $\leq 1 / 3$ of mean zone diameter of control.

e I: Intermediate activity $=$ Mean of zone diameter $\leq 2 / 3$ of mean zone diameter of control.

${ }^{\mathrm{f}} \mathrm{H}$ : High activity $=$ Mean of zone diameter $>2 / 3$ of mean zone diameter of control.

$\mathrm{g}$ Concentration, $\mathrm{mg} / \mathrm{mL}$.

h Chloramphencol in the case of Gram-positive bacteria, Cephalothin in the case of Gram-negative bacteria and cycloheximide in the case of fungi.

\section{Conclusion}

The Claisen condensation of 2-hydroxaceophenone derivatives with ethyl cyanoacetate gave condensation and cyclocondensation products with different nucleophilic reagents and depends on the reactivity of 2-hydroxyacetophenone, nucleophilic reagents, and the thermodynamic stabilities of the products. Also, the antimicrobial activities for the prepared compounds indicated that when coumarin derivatives bear a chromone moiety, the biological activities are increased compared with other prepared derivatives.

\section{References}

[1]. El-Sayed, A. M.; Abdallah, O. A. Phosphorus Sulfur 2001, 170, 75-86.

[2]. Periers, A. M.; Laurin, P.; Benedetti, Y.; Lachaud, S.; Ferroud, D.; Iltis, A.; Haesslein, J. L.; Klich, M.; LHermite, G.; Musicki, B. Tetrahedron Lett. 2000, 41(6), 867-871.

[3]. Ali, T. E.; Abdel-Aziz, S. A.; El-Shaaer, H. M.; Hanafy, F. I.; El-Fauomy, A. Z. Phosphorus Sulfur 2008, 183, 2139-2160

[4]. Ali, T. E.; Abdel- Aziz, S. A.; El-Shaaer, H. M.; Hanafy, F. I.; El-Fauomy, A. Z. Turk J. Chem. 2008, 32, 365-374.

[5]. El-Shaaer, H. M.; Foltinova, P.; Lacova, M.; Chovancova, J.; Stankovicova, H. Farmaco 1998, 53, 224-232

[6]. Gasparova, R.; Lacova, M.; El-Shaaer, H. M.; Odlerova, Z. Il Farmaco 1997, 52, 251-253.

[7]. Edwards, A. M.; Howell, J. B. L. Clin. Experim. Allergy 2000, 30, 756774.

[8]. Ishar, M. P. S.; Singh, G.; Singh, S.; Sreenivasan, K. K.; Singh, G. Bioorg. Med. Chem. Lett. 2006, 16, 1366-1370.

[9]. Liu, J.; Wu, J.; Zhao, Y. X.; Deng, Y. Y.; Mei, W. L.; Dai, H. F. Chin. Chem. Lett. 2008, 19, 934-936.

[10]. Nawrot-Modranka, J.; Nawrot, E.; Graczyk, J. Eur. J. Med. Chem. 2006, $41,1301-1309$.

[11]. Mao, P. C. M.; Mouscadet, J. F.; Leh, H.; Auclair, C.; Hsu, L. Y. Chem. Pharm. Bull. 2002, 50, 1634-1637

[12]. Kirkiacharian, S.; Thuy, D. T.; Sicsic, S.; Bakhchinian, R.; Kurkijan, R.; Tonnaire, T. Il Farmaco 2002, 57, 703-708.

[13]. Lacova, M.; Gasparova, R.; Kois, P.; Bohac, A.; El-Shaaer, H. M. Tetrahedron 2010, 66, 1410-1419.

[14]. Gaplovsky, A.; Donovalova, J; Lacova, M.; Mracnova, R.; El-Shaaer, H. M. J. Photoch. Photobio. A 2000, 136, 61-65.

[15]. El-Shaaer, H. M.; Perjessy, A.; Zahradnik, P.; Lacova, M.; Sustekova, Z. Monatsh. Chem. 1993, 124, 539-548.

[16]. Bauer, A. W.; Kirby, W. W. M.; Sherris, J. C.; Turck, M. Am. J. Clin. Path. 1966, 45, 493-496. 